\title{
Mineral Composition of Edible Crab, Charybdis Natator Herbst (Crustacea: Decapoda)
}

\author{
Soundarapandian $\mathrm{P}^{1 *}$, Varadharajan $\mathrm{D}^{1}$ and Sivasubramanian $\mathrm{C}^{2}$
}

${ }^{1}$ Faculty of Marine Sciences, Centre of Advanced Study in Marine Biology, Annamalai University, Parangipettai-608 502, Tamil Nadu, India ${ }^{2}$ Department of Zoology, Government Arts College, Dharmapuri, India

\begin{abstract}
Totally 11 minerals were reported in the present study. There are about 7 (Sodium $>$ Potassium $>$ Magnesium $>\mathrm{Ca}$ Icium>Manganese>|ron>Zinc) minerals were reported in all sexes. Sodium was maximum and zinc was minimum in all sexes. Copper, mercury and cadmium were available in trace amount in all sexes. However, arsenic was in trace amount in berried females and totally absent in males and females. Among different sexes, berried females contain maximum amount of minerals $(157.65 \mathrm{mg})$ followed by males $(117.30 \mathrm{mg})$ and females $(93.65 \mathrm{mg})$. From the study, berried females contains maximum amount of minerals than males and females. So it is recommended to consume berried females to get maximum minerals.
\end{abstract}

Keywords: Minerals; Copper; Mercury; Cadmium; Male; Female; Berried; Charybdis natator

\section{Introduction}

Nutrients play a vital role on physical growth and development, maintenance of normal body function, physical activity and health. Nutrition is a basic prerequisite to sustain life. Minerals constitute the micronutrients and are necessary for physiological and biochemical processes by which the human body acquires, assimilates and utilized food to maintain health and activity [1-3]. This not only promoting proper physical growth and development, but also in ensuring adequate immunocompetence and cognitive development. Low level of mineral causes some health problem [4-6]. Determination of mineral composition of crab is important for both checking raw material quality and labeling requirement in nutritional point of view. That kind of information gives the idea of choosing the best product for health. Studies on the mineral composition of crabs are very limited. So it is designed to determine the mineral composition of edible crab C. natator.

\section{Materials and Methods}

The male, female and berried females of $C$. natator were procured from Parangipettai (Lat. 11 $21^{\prime} \mathrm{N}$; Long. $79^{\circ} 46^{\prime} \mathrm{E}$ ) landing centres. The carapace of the crabs was opened and the edible parts of muscle tissues were removed with sharp forceps. The removed muscle tissues were homogenized with pestle and mortar. The grounded muscles were then freeze dried and powdered and eventually stored in refrigerator for further analysis. To the $5 \mathrm{~g}$ of crab tissue samples, mixture of hydrochloric acid, nitric acid and perchloric acid at a ratio of 10:5:1 was added for digestion at $30^{\circ} \mathrm{C}$. The digests were filtered suitably and aspirated in digital flame photometer (Modal No.CL 22D, Elico pvt, India), the values obtained were expressed in $\mathrm{mg} / 100 \mathrm{~g}$ [7].

\section{Statistical Analysis}

The data were subjected to One-way analysis of variance (ANOVA) and the difference between means were determined by Duncan's multiple range tests $(\mathrm{P}<0.05)$ using SPSS version 17.0.

\section{Results}

The mineral compositions of the C. natator muscle tissue are shown in Table 1 and Figure 1. Totally 11 minerals were reported in the present study. There are about 7 (Sodium $>$ Potassium $>$ Magnesium $>$ Calcium $>$ Manganese $>$ Iron $>$ Zinc) minerals were reported in all sexes. Sodium was maximum and zinc was minimum in all sexes. Comparatively berried females contain the maximum amount of minerals than males and females. Copper, mercury and cadmium were available in trace amounts in all sexes. However, arsenic was in trace amounts in berried females and totally absent in males and females. Among different sexes, berried females contain the maximum amount of minerals (157.65 mg) followed by males $(117.30 \mathrm{mg}$ ) and females $(93.65 \mathrm{mg})$.

\begin{tabular}{|c|c|c|c|c|c|}
\hline S.No & Minerals & Male & Female & Berried female & Total \\
\hline 1 & Calcium & $12.55 \pm 0.42$ & $11.52 \pm 0.38$ & $23.47 \pm 0.49$ & $47.54 \pm 1.25$ \\
\hline 2 & Magnesium & $20.01 \pm 0.53$ & $18.27 \pm 0.53$ & $30.54 \pm 0.32$ & $68.82 \pm 2.12$ \\
\hline 3 & Iron & $1.34 \pm 0.42$ & $1.05 \pm 0.42$ & $2.56 \pm 0.37$ & $4.95 \pm 1.21$ \\
\hline 4 & Sodium & $45.67 \pm 0.32$ & $36.45 \pm 0.41$ & $52.36 \pm 0.51$ & $134.48 \pm 0.56$ \\
\hline 5 & Potassium & $35.78 \pm 0.38$ & $24.86 \pm 0.49$ & $45.37 \pm 0.51$ & $106 \pm 0.38$ \\
\hline 6 & Zinc & $0.45 \pm 0.38$ & $0.25 \pm 0.38^{c}$ & $0.56 \pm 0.42$ & $1.26 \pm 1.28$ \\
\hline 7 & Copper & Trace & Trace & Trace & Trace \\
\hline 8 & Manganese & $1.50 \pm 0.38$ & $1.25 \pm 0.30$ & $2.79 \pm 0.28$ & $5.54 \pm 2.38$ \\
\hline 9 & Mercury & Trace & Trace & Trace & Trace \\
\hline 10 & Cadmium & Trace & Trace & Trace & Trace \\
\hline 11 & Arsenic & - & - & Trace & - \\
\hline \multicolumn{2}{|r|}{ Total } & $117.30 \pm 2.22$ & $93.65 \pm 2.98$ & $157.65 \pm 1.68$ & $368.60 \pm 2.11$ \\
\hline
\end{tabular}

Table 1: Mineral composition $(\mathrm{mg} / 100 \mathrm{~g})$ in the muscle of C.natator (Values are mean of three values \pm SE)

${ }^{*}$ Corresponding author: Soundarapandian P, Faculty of Marine Sciences, Centre of Advanced Study in Marine Biology, Annamalai University, Parangipettai-608 502, Tamil Nadu, India, Tel: 04144-243223, Fax: 04144-243553; E-mail: soundsuma@gmail.com

Received August 14, 2013; Accepted September 20, 2013; Published September 23, 2013

Citation: Soundarapandian P, Varadharajan D, Sivasubramanian C (2013) Mineral Composition of Edible Crab, Charybdis Natator Herbst (Crustacea: Decapoda). J Bioanal Biomed 5: 099-101. doi:10.4172/1948-593X.1000088

Copyright: (c) 2013 Soundarapandian P, et al. This is an open-access article distributed under the terms of the Creative Commons Attribution License, which permits unrestricted use, distribution, and reproduction in any medium, provided the original author and source are credited. 


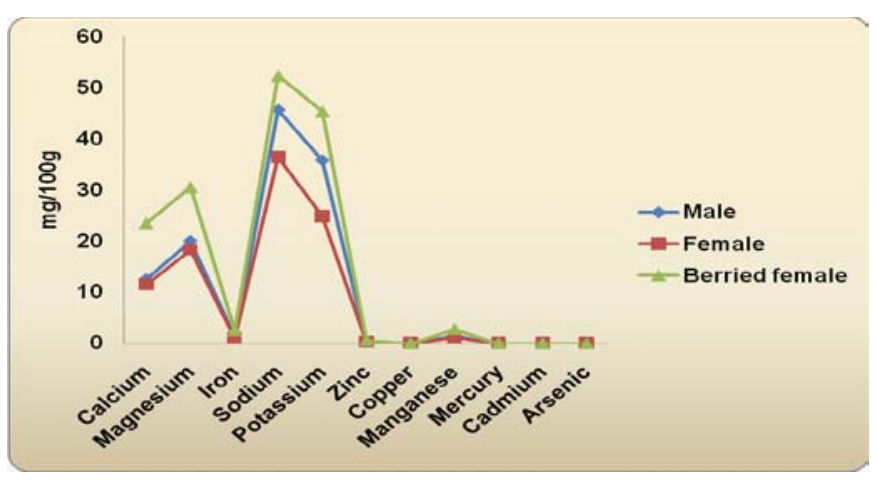

Figure 1: Mineral composition $(\mathrm{mg} / 100 \mathrm{~g})$ in the muscle of $C$. natator.

\section{Discussion}

Marine foods are very rich sources of mineral components. The total content of minerals in the raw flesh of marine fish and invertebrates is in the range of $0.6-1.5 \%$ wet weight. Mineral components such as sodium, potassium, magnesium, calcium, iron, phosphorus and iodine are important for human nutrition [8]. Crustaceans are also good sources of various minerals and high quality protein. Crab meat is an excellent source of minerals, particularly calcium, iron, zinc, potassium and phosphours [9-12]. Living organisms require trace amounts of some heavy metals including iron, cobalt, copper, manganese, molybdenum, strontium, vanadium and zinc. Excessive levels of these metals, however, can be detrimental to living organisms. Other heavy metals such as cadmium, lead and mercury have no known beneficial effect on organisms and their accumulation over time in the bodies of mammals can cause serious illness [13]. The fish and shellfish can absorb minerals directly from the aquatic environment through gills and body surfaces. Almost all the elements that occur in seawater are found to some extent in aquatic animals and these includes $\mathrm{Na}, \mathrm{K}, \mathrm{Ca}$, $\mathrm{P}, \mathrm{Al}, \mathrm{Ba}, \mathrm{Cd}, \mathrm{I}, \mathrm{Cr}, \mathrm{Pb}, \mathrm{Li}, \mathrm{Hg}, \mathrm{Ag}$, St and Va. Eyo [14] reported that the mineral content of fish makes unavoidable in the diet, as it is a source of different minerals that contribute to good health.

The minerals are serving as components of bones, soft tissues (Sulfur amino acids, metalloproteins) co-factors and co-activators of various enzymes important in human nutrition. Calcium, phosphorus, magnesium and electrolytes (sodium and potassium) are considered to be as macro elements and iron, copper, zinc, iodine, chromium, cobalt, manganese, molybdenum, selenium are considered as trace elements that are required for normal functioning, for instance the more soluble minerals such as $\mathrm{Ca}, \mathrm{P}, \mathrm{Na}, \mathrm{K}$ and $\mathrm{Cl}$ are involved in the maintenance of acid-base balance and membrane potential. The main functions of essential minerals include skeletal structure, maintenance of colloidal system and regulation of acid-base equilibrium. Minerals also constitute an important component of hormones, enzymes and enzyme activators [15].

Considering the elemental composition of common food items (dairy products, meat, fish, cereals and fruits), C.pagurus hepatopancreas is a good source of $\mathrm{Ca}, \mathrm{Fe}, \mathrm{Cu}, \mathrm{Zn}$ and $\mathrm{Se}[16,17]$. The more soluble minerals such as $\mathrm{Ca}, \mathrm{P}, \mathrm{Na}, \mathrm{K}$ and $\mathrm{Cl}$ also have osmoregulatary function and the maintenance of acid-base balance and membrane potentials [18]. Some elements such as $\mathrm{Mg}, \mathrm{Al}, \mathrm{Ca}, \mathrm{Fe}, \mathrm{Co}, \mathrm{Cu}$ and $\mathrm{Zn}$ are necessary for maintenance of optimum health thus are important from a nutrition point of view. Metals such as $\mathrm{Pb}, \mathrm{Cd}$, as and $\mathrm{Hg}$ are detrimental to optimum health and have toxicological effect and the tissue samples are also used as the bio-indicator to assess bioavailability of contaminant concentrations in coastal water in environmental studies [19]. The aquatic environmental/ecosystem and their inhabitants are exposed and sensitive to the effects of environmental pollution from heavy metal contamination. Aquatic animals accumulate large quantities of these xenobiotics and the accumulation depends upon the intake and elimination from their body [20]. Among different aquatic organisms; oysters, crab and mussels, accumulate large quantities of heavy metals due to their habitat and feeding nature. Many metals $(\mathrm{Co}, \mathrm{Cu}, \mathrm{Mn}$, $\mathrm{Fe}$ and $\mathrm{Zn}$ ) are essential trace elements for aquatic organisms and are involved in biochemical processes such as enzyme activation.

Totally 11 minerals were reported in the present study. There are about 7 (Sodium $>$ Potassium $>$ Magnesium $>$ Calcium $>$ Manganese $>$ Iro $\mathrm{n}>$ Zinc) minerals are reported in all sexes. Sodium is maximum and zinc is minimum in all sexes. Comparatively berried female contains the maximum amount of minerals than males and females. These are very much comparable with the studies of Hagashi et al., Anon and Thirunavukkarasu [21-24]. Investigated the mineral contents of blue crab; C.sapidus and swim crab P.pelagicus and suggested that $\mathrm{Na}$, $\mathrm{Ca}, \mathrm{Zn}, \mathrm{Cu}$ values for blue crab and swim crab were not significantly different. Trace elements content in haemolymph of normal and red sternum mud crab were observed by Sancharoen et al. [25]. The mineral contents of green tiger shrimp and speckled shrimp were also found in both species showed seasonal differences $(\mathrm{p}<0.05)$, except the $\mathrm{Ca}$ content in green tiger shrimp. The average $\mathrm{Ca}$ contents of green tiger shrimp and speckled shrimp were $60.28 \mathrm{mg} / 10 \mathrm{~g}$ and $60.44 \mathrm{mg} / 10$ g, respectively $[26,27]$ reported the concentration of nine elements ( $\mathrm{Zn}$, $\mathrm{Fe}, \mathrm{K}, \mathrm{Na}, \mathrm{Mn}, \mathrm{Cu}, \mathrm{Mg}, \mathrm{Ca}$, and $\mathrm{P}$ ) in different tissues of crab meat and edible viscera of Chinese mitten crab, E. sinensis. Mohapatra et al. [19] studied the concentration of 10 elements (ppm) (K, Ca, Mn, Fe, $\mathrm{Cu}, \mathrm{Zn}, \mathrm{Se}, \mathrm{Br}, \mathrm{Sr}$ and $\mathrm{Pb}$ ) in S. serata, S. tranquebarica, P.monodon, $P$.indicus and $M$. rosenbergii [24] assessed the minerals content of hard and soft shell crabs of P.sangiunolentus. In the present study calcium and megnesium alone contribute $50 \%$. Sodium is maximum in berried females than males and females of $C$. natator. Similar results were reported in P. sanguinolentus [24], S. tranquebarica [23] and E. sinesnsis [27]. Ca also has an essential role in blood clotting, muscle contraction and nerve transmission. Calcium is nutritionally very important (up to $1.9 \% \mathrm{Ca}$ is available in human body) and provides rigidity to the skeleton and plays a role in many metabolic processes [16]. It is also essential for hard tissue structure, blood clotting, muscle contraction, nerve transmission and osmoregulation and as a cofactor for enzymes procession [28]. The higher $\mathrm{Ca}$ content in male crabs are likely because this species has a sexual dimorphism, in which males have bigger claws and harder exoskeletons (composed of calcium phosphate). Particularly during the premoult period of C. pagurus, hepatopancreas accumulates $\mathrm{Ca}$ that is likely used in the exoskeleton calcification [29].

Magnesium is maximum in berried females than males and females. Magnesium was already reported in P. sanguinolentus [24], S. tranquebarica [23] and E. sinesnsis [27]. Magnesium is important for human nutrition and it is required for body's enzyme system. In addition to maintain bone health, magnesium acts in all cells of the soft tissues, where it forms part of the protein-making machinery and necessary for energy metabolism. Mg is cofactor for enzyme systems [30].

Iron is maximum in berried females than males and females. Iron was already reported in E. sinesnsis [27]. Iron is one of the very important essential trace elements since it has several vital functions in the human system. It serves as a carrier of oxygen to the tissues from 
the lungs by red blood cell. Adequate Fe in the diet is very important for avoiding some major health problems [15]. Adequate iron in the diet is very important for decreasing the incidence of anemia, which is considered a major health problem, especially in young children. Iron deficiency occurs when the demand for iron is high, e.g., in growth, high menstrual loss, and pregnancy, and the intake is quantitatively inadequate or contains elements that render the iron unavailable for absorption [15]. Transition metal ions, particularly $\mathrm{Cu}$ and $\mathrm{Fe}$, have been known as the major catalysts for oxidation [31]. Copper and iron are important minerals found in fish as respiratory pigment, while cobalt is present in vitamin $B_{12}$.

Sodium contribution is maximum irrespective of the sex. In individual contribution sodium is the highest in berried females followed by males and females of $C$. natator. Sodium was already reported in P. sanguinolentus [24], S. tranquebarica [23] and E. sinesnsis [27]. Sodium is the principal cation of the extra cellular fluid and regulator of its volume. Sodium also helps to maintain acid-base balance and is essential for nerve system. Potassium is maximum in berried females than males and females of $C$. natator. Potassium was already reported in P. sanguinolentus [24], S. tranquebarica [23] and E. sinesnsis [27]. Potassium is important to maintain the $\mathrm{pH}$, storage and transfer of energy and nucleotide synthesis. Zinc is maximum in berried females than males and females of C.natator. Zinc was already reported in P. sanguinolentus [24], S. tranquebarica [23] and E. sinesnsis [27].

Zinc is an essential trace element for all living species, since is an important component of several enzymes and plays an essential role in a number of biological processes involved in growth and development $[16,32]$ reported higher $\mathrm{Cu}$ and $\mathrm{Zn}$ accumulation in females than males of semaphore crab. Manganese is maximum in berried females than males and females of $C$. natator Manganese are important for the development of bones. It also acts as an activator of enzyme systems, but the connection with the deficiency symptoms in crustacean is not entirely clears. From the study berried females contains the maximum amount of minerals than males and females. So it is recommended to consume berried females to get maximum minerals.

\section{References}

1. Allen D, Gatlin DM (1996) Dietary mineral requirements of fish and marine crustaceans. Rev Fish Sci 4: 75-99.

2. Anon (1999) Results from the USDA, Nutrient database for standard reference crustaceans 1-3.

3. Mohapatra A, Rautray TR, Patra AK, Vijaayan V, Mohanty RK (2009) Elementa composition in mud crab Scylla serrata from Mahanadi estuary, India: in situ irradiation analysis by external PIXE. Food chem Toxicol 47: 119-123.

4. Dinakaran GK, Soundarapandian P (2009) Biochemical Status of Edible Palaemonid Prawn Macrobrachium idella idella (Hilgendorf, 1898). Adv J Food Sci Tech 1: 19-26.

5. Dinakaran GK, Soundarapandian P, Saunak Kumar C (2009) Proximate composition of edible palaemonid prawn Macrobrachium idae. Cur Res J Bio Sci 1: 78-82.

6. Dinakaran GK, Soundarapandian P, Tiwary AK (2010) Nutritional status of edible palaemonid prawn Macrobrachium scabriculum (Heller, 1862). European J Appli Sci 2: 30-36.

7. Guzman HM, Jimeneza CE (1992) Contamination of coral reefs by heavy metals along the Caribbean coast of Central America (Costa Rica and Panama). Marine Pollution Bulletin 24: 554-561.

8. Sikorski ZE (1990) Seafood: Resources Nutrional compositon and Preservation, Published by CRC Press, Boca Raton, Florida, USA.

9. Sifa L, Wanqi C, Shuming Chenhong ZL, Jinlang Z, Cheghui W (2000) Quality analysis of Chinese mitten crab Eriocheir sinensis in Yangchenghu Lake. J Fish China 7(3): 71-74
10. Adeyeye El (2002) Determination of chemical composition of the nutritionally valuable parts of male female common West African freshwater crab. Sudanautes africanus africanus. Int J Food Sci Nutr 53: 189-196.

11. Gokoglu N, Yerlikaya P (2003) Determination of proximate composition and mineral contents of blue crab ( Callinectus sapidus) and swim crab (Portuns pelagicus) caught off the Gulf of the antalya. Food Chem 80: 495-498.

12. Naczk M, Williams J, Brennam K, Liyanaspathiramma, Shahidi F (2007) Compositional characteristics of green crab (Carcinus sapidus). Food Chem 88: $429-434$

13. Hawkes SJ (1997) What is a heavy metal. J Chem Edu 74: 1374

14. Eyo AA (2001) Fish processing technology in the tropics. National Institute for freshwater, Fisheries Research University of Ilorin press. 66-70.

15. Belitz HD, Grosch W (2001) Schieberle, P.Lehrbuch der Lehbensmittelchemie, Aufl.Springer Verlag, berlin heidelberg New York.

16. FAO/WHO (2002) Human vitamines and mineral requirements. Report of joint food and Agricultural Organizations of the United Nations/World Health Organization Expert Consultation.Bankok, Thailand.

17. Martins I (2006) Food composition table. Health Institute Dr.Ricardo jorge. Centre of Nutrition and food safety of health Ministry, Lisbon, Portugal. p 355.

18. Davis DA, Lawrence AL, Gatlin DM (1992) Mineral requirements of Penaeus vannamei $A$ preliminary examination of the dietary essentiality for thirteen minerals. J World Aquacult Soc 23(1): 8-14

19. Mohapatra A, Rautray TR, Vijan V, Mohanty RK, Dey SK (2007) Trace elemental characterization of some food crustacean tissue samples by EDXRF technique. Aquacult 270: 552-558.

20. Karadede H, Oymak SA, Unlu E (2004) Heavy metals in mullet, Liza abu and catfish, Silurus triostegus from the ataturk Dam lake (Euphrates). Turkey Environ inter 30:183-188

21. Hagashi T, Asakawa A, Yamaguchi K, Konoso S (1979) Studies on flavour components in boiled crabs. Bull Japan Soc Sci Fish 45(10):1325-1329.

22. Anon (1999) Results from the USDA, nutrient database for standard reference crustaceans, Crab. blue, cooked, moist head. Blue crab-Nutrition html pp 1-3.

23. Thirunavukkarasu N (2005) Biology, nutritional evaluation and utilization of mud crab Scylla tranquebarica (Fabricius, 1798). Ph.D. Thesis, Annamalai University, India, p 126.

24. Sudhakar M, Manivannan K, Soundarapandian P (2009) Nutritive value of hard and soft shell crabs of Portunus sanguinolentus (Herbst). Inter J Ani Veter Advan 1: 44-48.

25. Sancharoen A, Thongpan A, Mingmuang M, Salaenoi J (2006) Morphology and hemolymph composition changes in red sternum mud crab (Scylla serrata). Kasetsart J Nat Sci 40: 158-166.

26. Yannar Y, Celik M (2006) Seasonal amino acid profiles and mineral contents of green tige shrimp (Penaeus seminsulcatus De Haan, 1844) and speckled shrimp (Metapenaeus monoceros, Fabricius, 1789) from the eastern Mediterrranean. Food Chem 94: 33-36.

27. Chen DW, Zhang M, Shrestha S (2007) Compositional characteristics and nutritional quality of Chinese mitten crab (Eriocheir sinensis ). Food Chem 103 1343-1349.

28. Lovel RT (1989) Nutrition and feeding of fish. New York: VannoStrandre in Hold, p 260

29. Luquet G, Marin F (2004) Biomeralization in crustaceans: storage strategies Comptes Rendus Palevol 3(6-7): 515-534

30. Food and Nutrition Board, National Research Council (1989) Recommended Dietary allowances, $10^{\text {th }}$ edn. Washington, DC; National academy Press

31. Thanonkaew A, Benjakul S, Visessanguan W, Deckar EA (2006) The effect of metal ions on lipid oxidation, colour and physioological properties of cuttlefish (Sepia pharaonis) subjected to multiple freeze thaw cycles. Food Chem: 210219.

32. MacFarlane GR, Booth DJ, Brown KR (2000) The Semaphore crab, Heloecius cordiformis: bio-indication potential for heavy metals in estuarine systems. Aquat Toxicol 50: 153-166 